\title{
The Two-Faced Hound: On the Existence of Chivalry and Its Relevance to Knighthood in George R. R. Martin's A Song of Ice and Fire and Tales of Dunk and Egg
}

\author{
Siavash Rohani \& Hassan Abootalebi \\ Jahad Daneshgahi (Isfahan), Iran
}

Received October 21, 2016; Revised December 12, 2016; Accepted December 20, 2016; Published January 14, 2017

\begin{abstract}
The current paper deals with the nature of knighthood and its connection with chivalry in George R. R. Martin's medieval fantasy series A Song of Ice and Fire (1996-) and Tales of Dunk and Egg (1998-). Taking place in the fictional world of Westeros, these novels portray a realm in which there is an increasingly growing rift between knighthood and chivalry. On one side of the rift, which is mainly spearheaded by Sandor "the Hound" Clegane, the practice of knighthood solely centers on the skill at swords and horsemanship, with chivalry and honor regarded as expendable decorations. On the other side, exemplary knights like Barristan Selmy and Duncan the Tall hold that, while martial skills are inseparable from knighthood, it is chivalry that distinguishes a knight from a common soldier. With an emphasis on the outlooks of the Hound on knighthood and chivalry, the current study aims to examine the character's sometimes conflicting attitudes towards his profession in an attempt to determine the accuracy of his claims on the irrelevancy of chivalry and knighthood, as well as the unreality of true knights.
\end{abstract}

Keywords: knight, chivalry, George R. R. Martin, A Song of Ice and Fire, Tales of Dunk and Egg.

\section{Introduction}

When discussing the Middle Ages, it is almost impossible to overlook the character of knights, an order of high-ranking warriors which played a great part in the making of that era. The legacy that the knights left with the world is as fascinating as it is rich, making them a recurring element in literature, movies and other popular culture. And while the definition of knighthood underwent some changes over the years, the core idea remained intact: that a knight was "a man with a high rank in the past who was trained to fight while riding a horse." (Longman Dictionary)

Although the founding of the order was primarily centered on martial activities, history informs that a cognate branch was later developed out of the original group, a class that involved itself mainly in religious pursuits and other ideologies and codes, but which still benefited from its members' warlike abilities. In A Concise History of Knighthood, Hugh Clark (1784) introduces these two divisions:

The different Orders of Knighthood are divided into two classes; the first consists of the Religious, which not only includes the defence of the Princes, the State, and of Christianity, but also by particular vows, and other Rules, renders them entirely under

(c) AesthetixMS 2016. This Open Access article is published under a Creative Commons Attribution Non-Commercial 4.0 International License (http://creativecommons.org/licenses/by-nc/4.o/), which permits non-commercial re-use, distribution, and reproduction in any medium, provided the original work is properly cited. For citation use the DOI. For commercial re-use, please contact editor@rupkatha.com. 
subjection to their chief. The second class comprehends the military, which Sovereigns have established to encourage the nobility, and keep emulation among their subjects in the wars, and the management of state affairs. (p. 3)

The amalgamation of these two classes also introduced the concept of 'chivalry'. In the context of knighthood, chivalry denoted "a system of religious beliefs and honorable behavior that knights in the middle ages were expected to follow." (Longman Dictionary) These beliefs and behaviors will be explained in the subsequent sections

Among the many literary figures who deal with knights in their works, a special mention must be made of George R. R. Martin, a celebrated American writer of science fiction, horror and fantasy stories who rose to global acclaim for his ongoing saga A Song of Ice and Fire, a series of medieval fantasy novels taking place in the fictional worlds of Westeros and Essos. In this series, as well as the spinoff novella collection called Tales of Dunk and Egg, Martin pays special attention to the portrayal of his knights, making great effort to simulate as closely as he could what it meant to be a knight in the ancient times, staying true to the feudalistic system that once used to dominate Europe. In his depiction of knighthood in the world of Westeros, Martin also introduces the 'true knight', a special version of knight who, in addition to his martial prowess, also upheld virtues like chivalry, loyalty, gallantry, honor and piety. True knight stands in direct opposition to 'false knight,' a darker counterpart to the chivalrous warrior who disregards (and often deliberately violates) the codes of chivalry and his holy vows.

The world of Westeros is populated by both true and false knights, as well as the regular type of knight who stands in-between the two extremities, and which is the most abundant kind in the Seven Kingdoms. Much like the real world, Martin also split the order of knighthood into the chivalrous and the secular. While the chivalrous class enjoys significant amount of respect among the commons as well as the highborn, as will be shown later, their inferior numbers and the difficulty of always upholding their numerous codes and vows discourage many from leading such a life. This discouraged attitude is shared among many characters in Westeros, but perhaps the strongest voice in this regard belongs to Sandor "the Hound" Clegane, who, in his frequent conversations with Sansa Stark, scorns and dismisses the concept and existence of the chivalrous true knight, insisting that all knights are killers, and thus, solely secular.

The Hound's cynicism towards knighthood stems from an early childhood tragedy. When a young Sandor is spotted by his elder brother Gregor playing with the latter's toy - a wooden knight - the furious older brother shoves his younger brother's face into a brazier as a punishment, burning half his face. Instead of facing punishment himself, Gregor's cruelty is instead covered up with a fake story of how young Sandor's bed caught fire which resulted in his burns. In a yet more ironic twist of fate, the same malicious Gregor was anointed as a knight a few years later, completely shattering Sandor's illusions about knighthood and all it stood for. Henceforth, Sandor Clegane went on believing that all knights are malicious in nature, that true knights never exist, and that a knight was no more than a decorated killer.

\subsection{Knighthood and chivalry}

The word 'knight' derives from the common West Germanic word knecht, meaning 'servant' or 'bondsman' (Online Etymology Dictionary). Nigel Saul (2001) in Chivalry in Medieval England, refers to the word's shared connotation with that of the French word chevalier:

The word knight, though Germanic in origin, carries the same meaning as the French chivalier, a knight, and both are connected with cheval, a horse. Chevalerie, the nearest 
contemporary approximation to 'chivalry', carries with it resonances of skill in the art of horsemanship. (p. 7)

Knighthood, thus, whether Germanic or French, was closely tied to horsemanship. In the martial context of the Middle Ages, however, the word knight took on a somewhat royal overtone. In Knights at Court, Aldo Scaglione (1992) provides such a definition for knights and knighthood: Knightly and knighthood... refer[ed] to the trained, horse-mounted warriors who formed a varied yet ideologically homogeneous group either within the titled and dubbed nobility or aspiring to become such-all these individuals operating mostly in courtly environments. (p. 8)

The earliest version of knight, as stated above, was solely centered on martial activities. In order to distinguish them from their later religious counterparts, as Scaglione informs, these secular knights were called 'milites', a sort of middle class warrior standing just above the peasants and just below the nobility: "the milites were recognized since A.D . 980 as a separate secular class or ordo, distinct from the rustici and immediately below the nobiles, until they eventually became part of the nobility" (pp. 17-8).

With the advent of Christianity, knighthood slowly embraced the doctrines of the church, advocating different values than their original ones. In The Archeology of Weapons, R. Ewart Oakeshott (1981) explains the duties of a Christian knight in the eleventh century Europe:

The knight in these years between 1090 and about 1050 had a religious mission; from the beginning of his career to its end he was the Church's servant, and the first article in his code was the defence of Christendom. (p. 90)

In all its definitions, however, a knight's most defining feature remained his horsemanship, which set him apart from his infantry counterparts. It is important to note that the concept of chivalry was not introduced to knighthood until the twelfth century, the time when, Scaglione (1992) notes, knighthood "reached its peak... the time of the flowering of "chivalry' or knightly ethos" (p. 17). The word chivalry derives from the Old French chevalerie which means "knighthood, chivalry, nobility, cavalry, art of war (Online Etymology Dictionary). Militaristically speaking, Charles Moeller (1908) defined chivalry as "the heavy cavalry of the Middle Ages which constituted the chief and most effective warlike force" (The Catholic Encyclopedia). According to Moeller, what really constituted chivalry was the knights' access to heavy armor and weaponry, ranging from the brunia or hauberk of the Carlovingian Era, the coat of mail, which prevailed during the Crusades, and lastly the plate armor introduced in the fourteenth century." The succeeding ages, however, understood chivalry in a different light, defining the concept as "honourable and courteous conduct expected of a knight" (Encyclopcedia Britannica). In "Chivalry during the Reign of King Edward III", Rich Lawson (2004) refers to these doctrines as "complex and often conflicting principles and ideals" which formed ideologies that "represented different medieval beliefs and standards, many of which often played a major role in medieval society." Among these contradictory ideologies were the "infusing [of] heroism and valor with two seemingly very different qualities," namely the sanctity of fighting and killing, and "the art of acing courteously."

Sophisticated in both nature and practice, chivalry thus came to denote a system of beliefs and behaviors that redefined the conducts of a knight from the twelfth century onwards. These codes, as explained by Oakeshott (1981), included "courtesy, humility, gallantry and, of course, religion" (p. 8) as well as "the love of women" 'feudal loyalty' honour, piety and love and 'gaiety'. It is important to note that gallantry, as explained by Charles Mills (1844) in The History of Chivalry, "did not...actually found the order, yet perhaps it caused the union to receive the last clause of its title (p. 6). Among these said values, the love of women (and therefore their protection) soon 
became "a predominant feature in chivalry." (Oakeshott, 1981, p. 101) In fact, it gained such importance that "religion and feudal loyalty [took] second place" (p. 102).

Knighthood under chivalry was thus lifted to a much higher status, or as Nigel Saul (2011) put it, to "a divinely ordained estate, a bulwark of society against disorder." (pp. 2-3). Hence the idea of the knight as the noble defender of people was born.

\section{Discussion}

This section deals with the concept of knighthood and chivalry in George R. R. Martin's series $A$ Song of Ice and Fire and Tales of Dunk and Egg in an attempt to examine the nature and existence of true knight as opposed to regular and false knight. Specifically, the views and deeds of Sandor "the Hound" Clegane will be examined under this light in an attempt to determine the accuracy and consistency of this character's perspectives on what it really means to be a knight in Westeros. The main argument of the essay is to point out to the Hound's wrong, biased assumption that, since most Westerosi knights are not true, chivalry itself is redundant and nonexistent. These arguments will then be countered by Ser Duncan the Tall and Ser Barristan Selmy, two cases of true knights who prove that upholding the codes of chivalry in Westeros is still a possible and worthy pursuit.

\subsection{No true knights vs. few true knights}

One of the Hound's most distinct remarks about true knights is that "there are no true knights" (Martin, 1998, p. 469). In order to gauge the truth in this argument, one first needs to ask these questions: what does the Hound really mean when he claims that there are no true knights? Does he mean that there are certain practical, knightly codes which otherwise no one cares to follow? Or does he echo Jaime Lannister's belief that adhering to all the codes eventually deconstructs them all, making it impossible to follow all the rules? (p. 493). In other words, are the knights at fault for not following the codes, or are the codes, in their totality, at fault for being contradictory in nature?

The history of Westeros records a noticeable number of men universally known as true knights, many of whom also happened to belong to the Kingsguard, a group of selected knights tasked with defending the king's life. Some of the more prominent names include: Serwyn of the Mirror Shield, Ryam Redwyne, Aemon the Dragonknight, Gerold Hightower, Arthur Dayne, Duncan the Tall and Barristan Selmy.

The close accounts of the White Book of the Kingsguard testify to these knights' devotion to chivalry and honor. So either the Hound has not read the White Book and is unaware of those names, or that he simply calls it a tome of lies, there is a huge discrepancy between what the Hound says and what Westeros has seen. The origin of the Hound's biased stance towards knights and knighthood is undoubtedly his elder brother's cruel treatment towards Sandor, which prematurely shattered the young boy's illusion of a true knight. And while he has every right to condemn his brother of being 'no true knight', his subsequent generalizing of all knights as similar versions of his malevolent brother seems a bit too overstretched, and at times, even childish. There is a difference between the words 'few' and 'none', however small it might be. The Hound believes that there are no true knights at all, yet even in his own lifetime, there is at least one instance of such a knight in his vicinity: Ser Barristan Selmy, who had been near the Hound for fifteen years, and no one could ever doubt his codes of conduct (Martin, 1996, p. 219). 
Therefore, when the Hound claims that there are no true knights, he is shrugging off a very important, living example, and is therefore not reliable in this case.

\subsection{Survival vs. sacrifice}

Life in the Seven Kingdoms is a harsh battle against overwhelming odds and the ever-present threat of death. Due to the generally warlike attitudes of each kingdom to the others, wars of different scales frequently erupt throughout Westeros, casting the world into a chaotic hell. At the center of this chaos stand the knights, who with the use of their superior arms and swordsman skills determine the fate of a kingdom. Due to the perilous nature of a knight's work, especially that of a true knight, however, many flinch from abiding by the chivalric codes and instead choose to value their own survival over their honor or their liege lord's safety. This attitude was also not uncommon in the medieval literature of the real world, where there was sometimes a duality of approach to the concept of knighthood: the spiritual Perceval and the survivalist Tristan. According to Scaglione (1992):

The chivalry of the Perceval story entailed a metaphysical, mystical, and theological level of courtois refinement in an effort to attain a supreme level of personal perfection. The courtliness of a Tristan, instead, involved personal survival in the real world of hostile social forces. (p. 6)

The Tristan model of knighthood greatly resembles the Hound's lifestyle, according to which personal matters like survival, accumulation of wealth and ascension to power take precedence over knightly duties. However, there should exist some sort of difference between a high-ranking knight and a regular lesser soldier, besides the quality of their weapons and armor. If a knight is held in such high esteem, should there not be some kind of price in exchange for his superior arms and incomes? This is where the chivalric codes come into play. Stemming straight from the traditions of the Andals, a knight of Westeros was expected to follow a certain number of holy vows and chivalric codes which defined who he is.

In A Dance with Dragons, Barristan Selmy, a famous true knight, calls chivalry "the code that made a knight more than any pit fighter." (2011, p. 639) expressly drawing a distinction between a common killer and a knight. In another occasion, while training some young boys to become knights, he goes on to name chivalry as the ultimate distinguishing factor of knighthood: "it is chivalry that makes a true knight, not a sword. Without honor, a knight is no more than a common killer. It is better to die with honor than to live without it"(p. 798).

These chivalric codes are assigned to a knight during his knighting ceremony, a certain set of rituals that always require the aspiring knight to swear a number of vows. During a traditional knighting ceremony, the knight-to-be is charged by his liege lord with the following missions:

In the name of the Warrior I charge you to be brave. In the name of the Father I charge you to be just. In the name of the Mother I charge you to defend the young and innocent. In the name of the Maid I charge you to protect all women.... (Martin, 1998, p. 42)

Different, shorter versions of these vows are also common. According to Ser Duncan in The Hedge Knight, his old master Ser Alran charged him "to be a good knight and true, to obey the seven gods, defend the weak and innocent, serve [his] lord faithfully and defend the realm with all [his] might" (p. 19). The similarities between the two versions are obvious. Both require the knight to defend the weak, the innocent, women, and the realm. As is clear from these words, the main essence of a knight's oath is to 'defend', not 'kill' or 'invade'. The vows do not direct a knight to kill his lord's enemies, but rather to defend his lord from his enemies, killing them only 
at the utmost need. Nigel Saul (2011) also reports that Christian knights of the medieval ages were similarly required to "wage war in a just cause, preeminently the recovery of the Holy Places from the infidel” (p. 3). Again, the word 'recovery' is used in a knight's duty instead of 'invasion', expansion or extermination.

These points are all largely missed out by the Hound in his interpretation of knighthood, as he firmly believes that knights are only good for killing, by which he means wanton slaughter: "Killing is the sweetest thing there is" (Martin, 1998, p. 468). The extent to which a knight may go to defend the weak may vary with each person, but the vows themselves make it especially clear that: "old or young, a true knight is sworn to protect those who are weaker than himself, or die in the attempt" (Martin, 2005, p. 370). This may seem a bit outstretched, but that is also one of the most distinguishing qualities that separate a knight from lesser soldiers. In fact, the knight's level of devotion to these vows is exactly what determines the value and truth of that knight.

The Hound, however, takes a different approach to knighthood. He attributes the utmost priority to his own survival rather than protecting other people's lives, an attitude which might be tolerated in a simple soldier or sellsword, but which is most inappropriate for a knight. In other words, the Hound acknowledges the advantages of knighthood without paying his dues to them, believing that any man who can afford to ride a horse and swing a sword skillfully can be called a knight:

A knight's a sword with a horse. The rest, the vows and the sacred oils and the lady's favors, they're silk ribbons tied round the sword. Maybe the sword's prettier with ribbons hanging off it, but it will kill you just as dead. (Martin, 2000, p. 321)

This argument is wrong in two ways. First of all, if knights are good for killing, does it not mean that they are also good for dying in defense of another man? The Hound's personal, biased view on the concept of knighthood favors survival over sacrifice, but it does not necessarily mean that every knight should follow the same road, or that giving value to other peoples' lives is wrong. It only means that the Hound is simply not ready to commit to the higher values of knighthood. Second, and more importantly, this statement stands in stark contrast with another one of the Hound's arguments, where he claims that, while a knight may flinch from sacrificing his life for his master, a dog (referring to himself) never does: "I like dogs better than knights... A hound will die for you, but never lie to you" (Martin, 1998, p. 181). This statement is also later proven to be based on shaky grounds, when the Hound shamelessly forsakes his king and his besieged city during the final phases of the Battle of Blackwater in A Clash of Kings, all because of his fear of fire, thereby nullifying his claim about his so-called canine loyalty to his master.

\subsection{Defender vs. killing machine}

No matter what definition of knight one chooses to follow, the fact remains unchanged that a knight is a warrior in essence, and warriors make war with their enemies, and kill them if need be. Even the most devout Christian knights were primarily used in warfare against the so-called Saracens during the Crusades. According to Richard W. Kaeuper (1999) in Chivalry and Violence in Medieval Europe: "the bloody-minded side of the code... was of the essence of chivalry. The knight was a warrior and not Everyman" (p. 18). The same is also true about knighthood in Westeros. Knights are primarily trained and hired for combat. Even Ser Arthur Dayne, one of the most outstanding true knights in the history of the Seven Kingdoms, affirms this fact when he teaches the young Jaime Lannister that: all knights must bleed, Jaime. Blood is the seal of our devotion. (Martin, 2005, p. 99). However, the amount of bloodletting as well as its cause can be a 
matter of dispute. Can a knight be considered a true knight if he kills people? Are all sorts of killings equally wrong? Is it right to call a knight a killer even if he only kills when necessary?

Two kinds of answers can be given to these questions. Idealistically speaking, killing people under any circumstances would be wrong, no matter what the cause might be. Realistically speaking, however, especially in the context of knighthood, not all killings might be considered wrong unless they are done wantonly or without proper cause, while those killings that are carried out under a just cause might be validated. In the case of the idealist, the Hound is ironically a very prominent example. Although he tries very hard throughout the series to display himself as a very practical, realist man who acknowledges the harshness, violence and injustice in the world, the Hound can also at times be very idealistic in his definition of knighthood. In fact, as it shall be discovered, the Hound keeps twisting the definition of knighthood and, with it, that of good and evil, with the sole intention of "winning" his arguments and justifying his own evilness in order to calm his guilty conscience. Throughout the series, the Hound constantly switches back and forth from realist to idealist in his definition of knighthood, making sure that he always stays on the safe side. Sometimes, when he is being unchivalrous, he ridicules the idea of chivalry in a knight: what do you think a knight is for, girl? You think it's all taking favors from ladies and looking fine in gold plate? Knights are for killing (Martin, 1998, p. 468). This dark view on knighthood borders close to the milites type of knight, which saw a knight as simply a highranking mounted soldier. Most killings in this context would then be justified as a knight's duty regardless of the manner or cause, and this would also go well the Hound's secular version of knighthood.

At other times, however, the Hound is seen harboring deep hatred towards those who behave unchivalrously towards him (including his brother). In fact, the Hound recognizes (and demands) chivalry as soon as it concerns his own rights. When captured and brought to trial by the Brotherhood without Banners in A Storm of Swords, who therefore intend to execute him for his numerous crimes, the Hound calls it murder: "might be you are knights after all. You lie like knights, maybe you murder like knights" (Martin, 2000, p. 321). This attitude stands in stark contrast with the Hound's earlier recognition of a knight as "a sword with a horse". And the Hound's use of 'murder' in the place of kill in this context is also very much unlike what he says and believes in other situations. The word murder has a negative connotation suggesting the 'illegal' killing of a person, whereas kill does not. In A Game of Thrones, The Hound murdered Mycah, an unarmed butcher boy falsely accused of attacking Prince Joffrey, and never cared to question the truth about the boy's guilt (p. 322) but when it comes to his own trial, he calls it murder simply because he does not want to die. Thus, by calling a knight's work murder, the Hound here implies that any knight who kills another (regardless of his manner or cause) is no different from a wanton killer, an attitude that is exceedingly idealistic, all the more when coming from a man who previously drew no distinction between killing and murdering. The Hound even goes as far as questioning the knighthood of the members of the Brotherhood without Banners in hopes of buying his freedom: "Knights? Clegane made the word a sneer. "Dondarrion's a knight, but the rest of you are the sorriest lot of outlaws and broken men I've ever seen. I shit better men than you" (p. 320). Here, unlike other instances, the Hound seems to expect more from knighthood besides swords and horses while, according to his previous definitions, a knight is only a sword with a horse, which would thereby make everyone in the Brotherhood a knight. But since a secular view on knighthood would not help the Hound escape his current situation, he switches easily to the idealistic version to save his life. 
Sansa Stark, on the other hand, has a different view on knighthood. Despite being one of the most romantic characters in A Song of Ice and Fire, her outlook on knighthood is not as idealistic as it first appears. In fact, what is idealistic about her is not her understanding of the concept of knighthood, but rather of the knights themselves. Born and raised with an infatuation with chivalric songs and virtuous knights, Sansa Stark came to believe that all knights are true and chivalrous, and therein lies her error, because true knights are far less common than regular or false knights. Yet even a romantic, docile character like Sansa Stark displays some traces of realism in her outlook on knighthood. Unlike the Hound, who sometimes scorns some rogue knights - especially his brother - for their malicious nature and killing sprees, Sansa does not view all types of killing wrong because she has a clear sense of morality which helps her judge the actions of others. Therefore, when news of Ser Gregor Clegane's raid on the villages of the Riverlands reaches the court and Ser Loras Tyrell volunteers to bring the false knight to justice, Sansa is quite pleased with the concept of Loras slaying Gregor: when the Knight of Flowers had spoken up, she'd been sure she was about to see one of Old Nan's stories come to life. Ser Gregor was the monster and Ser Loras the true hero who would slay him. (Martin, 1996, p. 323)

Furthermore, in A Clash of Kings, Sansa admits that her father Eddard Stark used to kill people sometimes, but she did not view them as wrong because she knew that her father did not take pleasure in it and that he regarded it as his duty: "Don't tell me Lord Eddard Stark of Winterfell never killed a man.That was his duty. He never liked it" (Martin, 1998, p. 468). These attitudes, especially when it comes from an innocent girl, shows that even Sansa is not totally abhorred by the idea of bloodshed as long as the sword is swung for a just cause, whereas the Hound would readily preach idealism where his own benefits are concerned.

\section{Conclusion}

The significant role of chivalry in shaping and polishing knighthood to its perfection is undeniable, as was its impact on the medieval societies' understanding of knighthood. The image of a knight during what was called 'the age of chivalry' greatly depended on his level of adherence to the knightly codes. And while chivalry was not everything that made a knight, it helped a great deal in keeping a knight's social status highly esteemed.

George R. R. Martin's medieval fantasy series A Song of Ice and Fire and Tales of Dunk and Egg present the world of Westeros, a world in which knighthood is torn between chivalry and warfare, with the knights pressured to choose between honor and survival. The austerity of life in Westeros leads many knights to forsake their vows and lead a life of dishonor rather than enduring the path of a true knight, with only a selected few still choosing honor over their own lives. And this rarity of true knights is exactly what makes people like Sandor "the Hound" Clegane veer too much towards the survivalist approach to knighthood while completely sacrificing their chivalry, disclaiming the existence of true knights in the process as well as the relevance of chivalry in knighthood.

However, as it was discussed earlier, such assumptions are wrong on several grounds. First of all, it is not accurate to claim that true knights are extinct simply because they are extremely rare. When compared to the entire population of the world, great men have always been heavily outnumbered by ordinary or vicious people, but that should not be understood as the extinction of decency. Westeros records a remarkable number of true knights who also belonged to the order of the Kingsguard, and who should be viewed not as far-fetched legends, but rather as paradigms of chivalry for other knights. 
The military profession of a knight should not be oversimplified to the extent of defining him as a 'killer' in the same sense that is used to describe a 'murderer'. The Hound, however, exhibits numerous traces of this pessimistic belief on the nature of a knight's work, stating that that "knights are for killing" while discarding of virtually everything else that accompanies them as "silk ribbons tied round the sword". On other occasions, however, the same character is seen accusing his captors of trying to 'murder' him on what he considers false accusations. This duality in the Hound's approach to knighthood testifies to the character's unreliable principles which only serve his own benefits and survival, even if it is gained at the cost of other peoples' rights.

Psychological projection is yet another disorder accountable for the Hound's irresponsible attitudes towards knighthood, a propensity to attribute all his misdeeds and malevolence to the "awful" world, thus making him virtually innocent. This attitude is wrong because of two reasons. First, the world is not a separate entity from the people who populate it, and so the evil actions of one man can and should be judged as part of the awfulness that made the world awful. And second, the Hound's belief that the entire world is awful simply because he himself has experienced a miserable life is another lie he keeps telling himself and the others despite the fact that, in the same "awful" world, there are also good, honest and honorable men who display all the virtues a person should possess, men like Eddard Stark and Barristan Selmy, both of whom the Hound ironically knew and derided for those same virtues.

In the end, the title of knighthood, in its correct form, entails more than mere skill at arms and horsemanship; it also requires chivalry and a sense of morality and honor. Like any other principle, it is, and should be, unaffected by the number of those who follow it as long as adhering to these codes helps to make the world a better place. Those who choose not to pursue these codes may not essentially be villains, but those who do definitely deserve to be called heroes.

\section{References}

Chivalry. (2016). In Encyclopcedia Britannica. Retrieved from http://www.britannica.com/topic/chivalry Cramer, P. (2006). Protecting the Self: Defense Mechanisms in Action. New York City: The Guilford Press. Hugh Clark. (1784). A Concise History of Knighthood. London: Oxford University.

Kaeuper. R. W. (1999). Chivalry and Violence in Medieval Europe. United Kingdom: Oxford University Press. Lawson, R. (2004, 07 08). Chivalry during the Reign of King Edward III. Retrieved from shadowedrealm: http://www.shadowedrealm.com/medieval-articles/exclusive/chivalry_king_edward_iii_reign

Martin, George. R. R. (1996). A Game of Thrones. New York City: Bantam Books.

---. (1998). A Clash of Kings. Bantam Books, New York City: Bantam Books.

---. (2000). A Storm of Swords. Bantam Books, New York City: Bantam Books.

---. (2005). A Feast for Crows. Bantam Books, New York City: Bantam Books.

---. (2011). A Dance with Dragons. New York City: Bantam Books.

---. (1998). The Hedge Knight. USA: Dabel Brothers Productions.

---. (2003). The Sworn Sword. USA: Dabel Brothers Productions.

Moeller, C. (1908). Chivalry. In The Catholic Encyclopedia. New York: Robert Appleton Company. Retrieved January 5, 2016 from New Advent: http://www.newadvent.org/cathen/o3691a.htm 
Mills, C. (1844). The History of Chivalry; Or, Knighthood and Its Times. Philadelphia: Lea and Blanchard Nigel Saul. (2011). Chivalry in Medieval England. USA: Harvard University Press.

Oakeshotte. R. E. (1981). The Archaeology of Weapons: Arms and Armour from Prehistory to the Age of Chivalry. USA: Dover Publications.

Scaglione, A. (1992). Knights at Court: Courtliness, Chivalry, and Courtesy from Ottonian Germany to the Italian Renaissance. Berkeley: University of California Press. 